\title{
THE REPORTS OF THE DAILY NEWSPAPER "POLITIKA" ABOUT THE SITUATION IN BOSNIA AND HERZEGOVINA PRECEDING THE ANNEXATION CRISIS OF 1908
}

\begin{abstract}
In this paper, the writings of the daily newspaper "Politika" regarding the events preceding the Annexation Crisis were analyzed. The political situation in Bosnia and Herzegovina at the beginning of the XX century was extremely complex and tense. Combined with the already complicated international circumstances, a favorable environment was created for one of the greatest political crises in Europe at the time. The period between the Young Turk Revolution and the Annexation Crisis was characterized by the attempts of Serbs from Bosnia and Herzegovina to resolve legally the question of Bosnia and Herzegovina without changing the state and legal status of the territory, as well as by the attempts by Austria-Hungary to integrate Bosnia and Herzegovina into its state structure. Austria-Hungary annexed Bosnia and Herzegovina and thus abused its mandate for occupying Bosnia and Herzegovina, which was provided by the Treaty of Berlin from 1878. The preparations for the annexation of Bosnia and Herzegovina were covered by the correspondents of "Politika", who informed the Serbian public about it. The articles published in "Politika" at the time are invaluable for obtaining an accurate picture of the state of affairs at the time, as well as of a reign of terror that the Austro-Hungarian rule imposed in Bosnia and Herzegovina.
\end{abstract}

Key words: Annexation, Bosnia and Herzegovina, 1908, Politika, Austria-Hungary, Serbia

\section{Introduction}

The beginning of the XX century was characterized by great diplomatic and political crises, which brought the world to the brink of war. The crises in that period were taking place in the areas where great powers held their interests, i.e., in the areas where their interests collided. "Little" nations were denied their rights and interests by great forces, or rather, if there were any, they had to be subjected to the interests of great forces. This treatment of smaller nations by the Great Powers led to

\footnotetext{
${ }^{1}$ Received November 2020 / Accepted December 2020

${ }^{2}$ E-mail: milan.videnovic@filfak.ni.ac.rs

${ }^{3}$ This paper is the result of the research that is a part of the project Historical Legacy of the Balkans through Centuries (from the Ancient to Modern Age) (no. 360/1-16-2-01) of the Department of History of the Faculty of Philosophy in Niš.
} 
dissatisfaction and the wish for some kind of confrontation. One such crisis had the Serbian people and their national interests on one side and Austria-Hungary and its imperial interests on the other. Alongside the interests of the Kingdom of Serbia and the Austro-Hungarian Empire, there were also interests of other states and peoples, which pervaded the preparation, breakout, reaction and the solution to the Annexation Crisis. This period was characterized by states taking either one or the other side in the dispute, which was a national issue to one of the countries and the realization of the first phase of its imperial tendencies for controlling the territories in the Balkans to the other. If we know that the act of annexation had been carefully prepared in advance, then it is also important to depict how those preparations appeared to the general public. An excellent source of events in Bosnia and Herzegovina is the daily newspaper "Politika", which, at the time, had correspondents not only in Bosnia and Herzegovina but also around the world.

\section{The daily newspaper "Politika" in the years before the annexation}

"Politika" is the oldest Serbian daily newspaper in continuous publication. Since the beginning of its existence, this newspaper has covered all significant events in Serbian history and all the adversities that the Serbian people faced in the XX century. We need to clarify that "Politika" was not created only by journalists; there were also writers and poets, artists, scientists, workers and merchants. Members of all social classes participated in creating the newspaper and we can freely say that "Politika" in the first half of the XX century was "the daily newspaper of the people". The period it was created in was a historical turning point, not only in Europe and the world but also in the Serbian civic society. It is also important to note that the influence of "Politika" did not stem from political power or financial support, but rather from the Serbian public opinion. The Serbian public, as it was later revealed during the Annexation Crisis and the events that followed, had great confidence in "Politika" (Миливојевић 1984: 5).

The first issue of "Politika" was released on January $12^{\text {th }}, 1904$, according to the Julian calendar. From the viewpoint of today, one could think that the appearance of a new daily newspaper was a significant thing among the Serbian public, but that was not the case, as there were more than 13 daily and 60 weekly or periodical newspapers in Belgrade alone (Миливојевић 1984: 11). However, all those newspapers were mostly instruments of political parties, i.e., they were propaganda pamphlets rather than real investigative newspapers. When it appeared, "Politika" did not resemble any existing newspaper in Serbia. Already in the first issue, with a message to its readers and the general public, it left a strong impression. Namely, in the introduction to the first issue of "Politika", it was stated that the newspaper would be independent from political parties and any kind of government, with a strong emphasis on being critical and objective. This kind of approach appealed to the cultural elite immediately and then it quickly became popular among others as well, making "Politika" the 
most reputable and the most widely read newspaper in Serbia in only a few years. Vladislav Ribnikar was the man most responsible for the establishment of "Politika" (Миливојевић 1984: 12). The suggestion to name the newspaper "Politika" was given by dr. Radivoj Vukadinović, and the logo for the name was conceived by Vladislav Ribnikar (Миливојевић 1984: 13-14).

Very quickly, "Politika" gathered the Serbian elite of the time. Among its associates, there were philosopher Branislav Petronijević, historian Stanoje Stanojević, ethnographer Jovan Cvijić, grammar school professor Stevan Sremac, writers Branislav Nušić and Veljko Petrović, as well as numerous other contributors. It is also important to note that, at the time, "Politika" employed a female journalist, Maga Magazinović from Užice, who wrote the column titled: "The Female World". Therefore, taking all these things into consideration, we can say that "Politika" was the first modern daily newspaper in Serbia, which brought about significant changes in Serbian journalism, and that it was no coincidence that it played a vital part in the history of Serbia at the time of the Annexation Crisis which started on October $5^{\text {th }}$, 1908 (Миливојевић 1984: 18-26).

\section{The international circumstances before the Annexation Crisis}

The Great Eastern Crisis (1875-1878) ended in 1878 with the Treaty of Berlin. After the articles of this treaty came to power, the last age of "old Europe" was created. ${ }^{4}$ This period was characterized by a series of international crises, which would result in the breakout of World War I. At the beginning of the XX century, two conflicts became prominent: the conflict between Austria-Hungary and Russia regarding the influence in the Balkan Peninsula and the conflict between Britain and Germany about world domination (Попов 2008: 242).

Germany obtained concession rights from Turkey for building the Baghdad railroad, which was to become the main instrument of Germany for spreading to the East (Поповић 1928: 157). In the beginning, Germany did not show a particular interest in the Balkans, because the area of the Balkans was considered to be the interest of Austria-Hungary (Потемкин 1949: 151-157). German diplomacy soon realized that Austria-Hungary was their most trusted ally, which is why they decided to support her attempts to spread to the Balkans (Бyxa 2008: 226).

Great Britain soon realized what direction the international relations were taking, so they signed a treaty with France in 1904 and with Russia in 1907 (Потемкин 1949: 144-160). ${ }^{5}$ Next to Great Britain, France was the second greatest colonial power in the

\footnotetext{
${ }^{4}$ The Great Eastern Crisis (1875-1878) was the name of the crisis that occurred on the territory of the Ottoman Empire, which started with the rebellion in Bosnia and Herzegovina and continued with the First and Second Serbian-Turkish War, as well as with the Russian-Turkish War (1877-1878). This crisis ended with a peace conference known as the Congress of Berlin in 1878.

${ }^{5}$ The treaty signed in London in 1904 signaled the end of the isolation of France and a mutual understanding about the division of interests. As a way of naming this agreement, the expression "entente" was used. When the agreement in Saint Petersburg was signed in 1907, the entire alliance
} 
world. The main aim of French politics, after 1871 and the unification of Germany was to create an alliance against Germany (Попов 2008: 244-247). The percent of French financial capital increased significantly after 1906 (Поповић 1928:157).

Italy had great aspirations in the Balkan Peninsula. It had the aim to assume control over the territories of present-day Albania, which would enable it to further penetrate the Balkans. Aside from Albania, the Adriatic coast was particularly important to Italy (Поповић 1928: 154).

Austria-Hungary needed the territory of the Balkans in order to spread its influence eastward. Having obtained the rights to occupy Bosnia and Herzegovina and keep a garrison in the Sanjak of Novi Pazar in 1878 marked an important turning point in its aspirations to achieve its goals in the Balkans. The occupation of Bosnia and Herzegovina disrupted the political balance in the Balkans at the detriment of Russia (Поповић 1928: 148).

After signing the Treaty of Berlin in 1878, Turkey lost control of a significant part of the Balkan Peninsula. The autonomous Principality of Bulgaria was created, Serbia and Montenegro gained independence, and the territory of Bosnia and Herzegovina was occupied by Austria-Hungary. The great powers tried to resolve the tension in Macedonia with the Mürzsteg Agreement in $1903^{6}$. The Young Turks carried out a revolution in 1908 in an attempt to improve the situation in the Ottoman Empire, but their attempt yielded no results (Мантран 2002: 662-630).

In its column dedicated to foreign policy, "Politika" reported in great detail on all significant events preceding the Annexation Crisis. For example, they wrote about the meeting in Bad Ischl between the British king and the Austro-Hungarian emperor. Great Britain performed a series of steps in an attempt to exclude Austria-Hungary from the reformative actions in Macedonia ${ }^{7}$. Italy joined the agreement made by Russia and Great Britain, even though Germany tried everything to win Italy over to their side. After failing to do so, Germany tried to persuade France, but the French government did not authorize a meeting between the German emperor and president Fallières ${ }^{8}$. Diplomatic activity was significantly increased in this period. A meeting between the German Kaiser William and the Russian Tsar Nikolai was announced. The two emperors discussed the situation in Turkey and entirely agreed that the plan for the reformation of Macedonia should be postponed. The tension that was present in the Balkans was only a part of a considerable tension that was present in all of Europe. ${ }^{10}$

between France, Russia and England was named the Triple Entente, or simply Entente.

${ }^{6}$ After the Ilinden Uprising against the Ottoman Empire failed in Macedonia in 1903, the Great Powers in Mürzsteg agreed on a program of reforms for the territories of the Bitola, Thessaloniki, and Kosovo vilayets. The reforms were known as the Mürzsteg reforms and they were partially conducted by the Great Powers between 1904 and 1909.

${ }^{7}$ Политика, 1. август 1908, бр. 1630, 1, Састанак у Ишлу.

${ }^{8}$ Политика, 3. август 1908, бр 1632, 1, Немачка акција.

${ }^{9}$ Политика, 4. август 1908, бр 1633, 1, Састанак руског и немачког цара.

${ }^{10}$ Политика, 7. август 1908, бр. 1636, 1, Енглеска и Немачка. 
After the revolution in Turkey broke out, Russia suggested to other great powers that the reformative actions in Macedonia be postponed until the outcome of the events in Turkey became known. Aehrenthal ${ }^{11}$ agreed, for the unstable situation in Turkey was beneficial to Austria-Hungary, as it made it easier for them to promote their interests in Bosnia and Herzegovina ${ }^{12}$. "Politika" published the news that England, i.e., the English king, supported the annexation of Bosnia and Herzegovina in Bad Ischl. The representatives of Austria-Hungary allegedly agreed for Bosnia and Herzegovina to maintain a certain degree of autonomy ${ }^{13}$. In the Serbian public, more and more people supported the idea to prevent the possible annexation of Bosnia and Herzegovina with a joint action with Turkey. Serbia preferred for Bosnia and Herzegovina to remain autonomous under the Turkish sultan than for it to be seemingly autonomous under Austro-Hungarian rule ${ }^{14}$. On August $27^{\text {th }}, 1908$, the Young Turks denied the claims of European newspapers that the Young Turk Parliament would demand returning Bosnia and Herzegovina under Ottoman rule ${ }^{15}$.

The Russian and the French ministers of foreign affairs, Izvolsky and Clemenceau met with the English king Edward in Marienbad, on August 27 ${ }^{\text {th }}$, 1908. King Edward spoke with Izvolsky about the situation in Turkey and Balkan railroads, whilst with Clemenceau, he spoke about the status of Morocco ${ }^{16}$. During this period, Marienbad served as a kind of diplomatic center, a spa where all the monarchs of Europe went on holiday. From the writings of "Politika", on September $9^{\text {th }}, 1908$, we could notice a dose of speculation, but also a faith in Russia, as it was considered that Russia would not let Bosnia and Herzegovina be given to Austria-Hungary ${ }^{17}$. Ali Riza, one of the leaders of the Young Turks, met with Aehrenthal in Vienna and declared that Turkey was satisfied with the status quo ${ }^{18}$.

On the pages of "Politika", it could be seen that Bulgaria was planning to declare itself an empire. This was supposed to be performed by forming local boards that would be in charge of collecting signatures, which would later be given over to Bulgarian General Savov and Prince Ferdinand, who would then declare the Bulgarian empire. This plan was followed by constant tensions between Bulgaria and Turkey, which was all part of the plan for the Bulgarian declaration of independence and the annexation of Bosnia and Herzegovina by Austria-Hungary ${ }^{19}$.

\footnotetext{
${ }^{11}$ Alois Lexa von Aehrenthal -the Minister of Foreign Affairs of the Austro-Hungarian Empire from 1906 to 1912.

${ }^{12}$ Политика, 10. август 1908, бр. 1639, 1, Одговор на руску ноту.

${ }^{13}$ Политика, 11. август 1908, бр. 1640, 3, Анексија.

${ }^{14}$ Политика, 12. август 1908, бр 1641, 1, Анексија и Турска.

${ }^{15}$ Политика, 15. август 1908, бр 1644, 1, Један Турски демант и Босанско питање.

${ }^{16}$ Политика, 16. август 1908, бр 1645, 1, Извољски и Клемансо.

${ }^{17}$ Политика, 27. август 1908, бр. 1656, 1, Ревизија Берлинског уговора.

${ }^{18}$ Политика, 11. септембар 1908, бр. 1671, 2, Ахмед-Риза.
} 


\section{The reports of "Politika" about the events prior to the act of annexation}

In legal terms, Bosnia and Herzegovina were still under the rule of the sultan. However, the Austro-Hungarian government slowly modified the social system to resemble the one in the territories belonging to the Empire (Потемкин 1949: 5051). Serbian people in Austria-Hungary could not form a unified whole, as they did not live on a common territory. One part lived in Austria, the second part was under Hungarian rule, the third in Croatia and Slavonia and the fourth in Bosnia and Herzegovina. These circumstances only aggravated the chances of gathering Serbian people into a unified whole. This suited the court in Vienna, as it made the influence that Serbs had on making decisions within the Empire very trivial (Ћоровић 1992: 351).

In their tendencies to invade the Balkans, Austro-Hungarian interests directly oppose Serbian national interests. Thus, it was known that any change in the status of Bosnia and Herzegovina would provoke a reaction from Serbia (Потемкин 1949: 52). When Baron Alois von Aehrenthal became the minister of foreign affairs of Austria-Hungary, the policy of the empire became more aggressive. Aehrenthal, who was very energetic, had the ambitions of restoring the honor of the Monarchy and strengthening its status as a Great Power in Europe. This period was marked by different events. Thus, in September 1908, Aehrenthal negotiated with the Russian minister of foreign affairs Izvolsky. The two ministers discussed the annexation of Bosnia and Herzegovina and the Russian interests on the Bosporus and the Dardanelles (Буха 2006: 109). "Politika" also wrote about these events.

"Politika" followed the activities of the Austro-Hungarian administration in Bosnia and Herzegovina. The imperialist policy of the Monarchy had the goal to cause discord among the Slavic part of the population and then to subdue them ${ }^{20}$. In an attempt to cause some sort of legal intervention against the colonial tendencies of Austria-Hungary in the Balkans, the Serbian emigration introduced the delegates of the Hague Convention with the difficult position the Serbian population in Bosnia and Herzegovina was $i^{21}$. An article in "Politika" from July $25^{\text {th }}, 1907$, titled "Austria Threatens" discusses various provocations that Austria-Hungary attempted. In this article, it was clearly stated that, from August $1^{\text {st }}$ to August $7^{\text {th }}$, Austria-Hungary was preparing to perform military exercises with two battalions near Pančevo, along with the support of their Danube fleet. The soldiers had the task of making a bridge and thus making the necessary preparations for entering the territory of the Kingdom of Serbia $^{22}$.

"Politika" gives an analysis and an assessment of the state of affairs in Bosnia and Herzegovina, paying special attention to two events from May $24^{\text {th }}$ and November $8^{\text {th }}$, 1907. The first event was the proclamation of the Sarajevo resolution, which stated the

\footnotetext{
${ }^{20}$ Политика, 25. јун 1907, бр. 1218, 2, После 30 година.

${ }^{21}$ Политика, 9. јул 1907, бр. 1232, 2, Меморандум босанско-херцеговачке емиграције.

22 Политика, 12. јул 1907, бр. 1235, 1, Аустрија прети.
} 
necessity of organizing the Serbian people in Bosnia and Herzegovina into a unified national organization, which would fight the oppressing rule of Austria-Hungary. The other event was a meeting of 70 members of parliament who discussed the situation in Bosnia and Herzegovina. The result of these discussions was passing the "Program of the Serbian National Organization in Bosnia and Herzegovina 23". The newspaper "Politika", in an article dated December $8^{\text {th }}, 1907$, called "Representing the People in Bosnia and Herzegovina", gave an assessment of the situation in Bosnia and Herzegovina and discussed the measures that Austria-Hungary should take in order to ensure political rights of the peoples in the occupied territories. It was further stated that the Austro-Hungarian administration should acknowledge the majority of the demands of the people ${ }^{24}$.

Austria-Hungary also attempted a series of intelligence and diplomatic activities that had the goal of causing discord among the Balkan states, which would thus pose far less of a threat to the interests of Austria-Hungary in the Balkans ${ }^{25}$. In its attempts to cause a conflict in the Balkans, i.e., to divide Serbia and Montenegro, AustriaHungary used Đorde Nastić ${ }^{26}$ and a few Montenegrin migrants and attempted to assassinate Prince Nikola, blaming Serbia for the act. After a failed assassination, there was a trial, which was supposed to prove the connection of the conspirators to the Kingdom of Serbia ${ }^{27}$. The trial attracted a lot of attention from the European press ${ }^{28}$. "Politika" wrote about the undercover work of Đorđe Nastić, who was approached by Austria to cause a conflict between Montenegro and Serbia, in their issue dated June $6^{\text {th }}, 1908^{29}$.

"Politika" also published the Resolution of the Association of Serbian Journalists, which stated that the Austro-Hungarian administration tried to portray Serbia as the main instigator of all acts, not only against Austria-Hungary but also against the rightful ruler of Bosnia and Herzegovina, Sultan Abdul Hamid. One article in the magazine "Otadžbina" from Banja Luka caused all members of the

\footnotetext{
${ }^{23}$ Политика, 14. новембар 1907, бр. 1410, 1, Српска акција у Босни и Херцеговини.

${ }^{24}$ Политика, 25. новембар 1907, бр. 1421, 2, Народно представништво за Босну и Херцеговину.

${ }^{25}$ Политика, 2. март 1908, бр. 1519, 2, Аустрија опет помишља на анексију..

${ }^{26}$ Đorđe Nastić, a Serb from Bosnia and Herzegovina, who participated in several controversial events. In historiography, it is accepted that he was working for Austria-Hungary. In the beginning, he was a member of Serbian national organizations. Before the annexation of Bosnia and Herzegovina, he revealed a plan to assassinate the Montenegrin Prince Nikola (in the event known as the Bomb Affair). He also attempted to cause a crisis in Bosnia and Herzegovina by revealing the alleged intentions Serbia had towards Bosnia and Herzegovina.
}

\footnotetext{
${ }^{27}$ This event is also known as the "Bomb Affair" and it was a diplomatic incident between the Kingdom of Serbia and the Kingdom of Montenegro. According to Đorđe Nastić, Serbia officially tried to prepare and perform the assassination of King Nikola and his family, which led to tension between the two countries.
}

${ }^{28}$ Политика, 13. мај 1908, бр. 1581, 1, Суђење на Цетињу.

${ }^{29}$ Политика, 24. мај 1908, бр. 1592, 2, Ђорђе Настић. 
editorial office to be accused of high treason ${ }^{30}$. On July $4^{\text {th }}, 1908$, "Politika" wrote of the persecution of Serbian intellectuals in Bosnia and Herzegovina. The article, titled "A Desperate Man", reported of the case of the writer Petar Kočić, who began his hunger strike at the time ${ }^{31}$. Articles like this caused a revolt among the Serbian public. Aside from the arrests that started immediately after "Nastićs findings", many Serbs were driven from Bosnia and Herzegovina. Thus, on August 14 $4^{\text {th }}, 1908$, Jovan Cvijić was cast out of Herzegovina. Aside from writing about Cvijić, on August 15 ${ }^{\text {th }}, 1908$, "Politika" published the article "The Serbian Exile", and in it, the information that Bosnia and Herzegovina will be given a constitution in August, which was supposed to be an attempt of Austria-Hungary to placate the Serbian people ${ }^{32}$. The constitution included the founding of local assemblies in every county, i.e., six cantonal self-ruling governments, which would allow Serbian people to take part in the regime. The court in Vienna saw that as a way of showing that its intention, in fact, was to provide Bosnia and Herzegovina with a constitution, but that it was not able to do so because of the alleged Serbian propaganda about creating Greater Serbia, which jeopardized the unity of Austria-Hungary ${ }^{33}$.

News quickly came from Petrograd that Austria-Hungary was planning to occupy Novi Pazar ${ }^{34}$. The Austro-Hungarian military mail confiscated all Serbian daily newspapers in Novi Pazar ${ }^{35}$. Also, ban Rauch ${ }^{36}$ prohibited the Serbs from flying their flags on the birthday of Franz Joseph, while the newspaper "Pester Lloyd" reported that the disloyal Serbian people did not fly a single flag in the honor of the birthday of the emperor ${ }^{37}$. The Kingdom of Serbia tried everything in its power to prevent a conflict with Austria-Hungary. "Politika" published the statement of minster Milovan Milovanović in an article titled "Mr. Milovanovićs Speech", dated August $14^{\text {th }}, 1908$, where it was stated that the Serbian National Assembly had passed a trade agreement with Austria-Hungary in order to stop the trade war between the two neighboring states. In the same article, it was stated that the newspaper "N. Sl. Presa" published an article about Đorđe Nastić and the so-called propaganda about

${ }^{30}$ Политика, 2. април 1908, бр. 1540, 2, Резолуција Српског новинарског удружења поводом догађаја у Бања Луци.

${ }^{31}$ Политика, 21. јун 1908, бр. 1620, 2, Очајник; At that moment, Petar Kočić was incarcerated for his writings in the newspaper "Otadžbina", which were directed against the Austro-Hungarian Empire. He began a hunger strike because of the poor conditions in the prison, as well as because his request for the sentence to be postponed had been denied.

32 Политика, 2. август 1908, бр. 1631, 2, Протеривање Срба.

${ }^{33}$ Политика, 2. август 1908, бр. 1631, 1, Босански устав.

${ }^{34}$ Политика, 4. август 1908, бр. 1633, 2, Окупација Новог Пазара..

${ }^{35}$ Политика, 5. август 1908, бр. 1634, 2, Аустрија у Санџаку.

${ }^{36}$ Pavle Rauch was a ban of Croatia from 1908 to 1910 . He helped destabilize the situation in Bosnia and Herzegovina before the Annexation. He also had a role in turning public opinion against the Serbian people, which resulted in the separation of the Croat-Serb coalition, which held the majority of votes in the Croatian assembly.

${ }^{37}$ Политика, 11. август 1908, бр. 1640, 3, „Нелојални“ Срби. 
Greater Serbia, accusing Serbia of having revolutionary intentions in Croatia ${ }^{38}$. It was interesting that, even among the public in Vienna, but also among the people close to ban Rauch, it was considered that the Nastić affair was ridiculous, and that nobody actually believed what Đorđe Nastić had presented ${ }^{39}$. Nevertheless, the affair was an excellent excuse for the Austro-Hungarian administration to deal with the Serbian people, who were supposed to remain unstirred during the annexation of Bosnia and Herzegovina. The first arrests of Serbs who were accused of high treason were made in Dubica and Dvor ${ }^{40}$. The Serbian people wanted to preserve the autonomy of Bosnia and Herzegovina under the rule of the sultan.

Intolerance of the Serbs in Bosnia and Herzegovina grew worse every day. The offices of the newspapers "Narod" and "Srpska riječ" were forcefully searched, while their employees were placed under police surveillance. No proof was found for the false claims made by Nastić. ${ }^{41}$ In the article "Bosnia and Nastic", it was stated that this form of terror in the beginning could be an introduction to some form of military dictatorship. The possibility of the annexation of Bosnia and Herzegovina was also mentioned ${ }^{42}$. As time passed, the complex plot surrounding Nastić unraveled increasingly and the connection was discovered between Đorđe Nastić and a journalist, Isidor Steinhardt ${ }^{43}$.

The arrests all across Bosnia and Herzegovina which were caused by the Nastić affair were occurring more and more often. One day, 28 notable people were arrested in Nevesinje alone ${ }^{44}$. Various evidence was found that allegedly connected them to the conspiracy. In the house of the Živković brothers, a record was found with the Serbian song "Vesela je Srbadija", while in the house of Bekić, a tapestry with the Serbian coat of arms was found ${ }^{45}$. During the meeting of ministers in Vienna, held on August 18 ${ }^{\text {th }} 1908$, "propaganda about Greater Serbia” was discussed, and it was agreed that it was too early for making a constitution for Bosnia and Herzegovina, because its peoples did not reach the degree of cultural development needed to effect successfully democratic changes ${ }^{46}$. Since the Nastić affair in Austria-Hungary, there were more and more mentions of the annexation of Bosnia and Herzegovina. In the international public, it was necessary to create the impression that the masses in Bosnia and Herzegovina demanded to be annexed by Austria-Hungary. Thus, based on his instructions from Vienna, vice-president of the Sarajevo municipality, Mandić,

\footnotetext{
${ }^{38}$ Политика, 1. август 1908, бр. 1630, 1, Говор г. Миловановића.

${ }^{39}$ Политика, 3. август 1908, бр. 1632, 1, Генезис.

${ }^{40}$ Политика, 2. август 1908, бр. 1631, 2, Инквизиција.

${ }^{41}$ Политика, 4. август 1908, бр. 1633, 2, Инквизиција.

42 Политика, 5. август 1908, бр. 1634, 1, Босна и Настић.

${ }^{43}$ Политика, 5. август 1908, бр. 1634, 2, Настић и Штајнхарт.

${ }^{44}$ Политика, 6. август 1908. бр. 1635, 2, Хапшења у Невесињу.

${ }^{45}$ Политика, 7. август 1908. бр. 1636, 2, Истрага се наставља.

${ }^{46}$ Политика, 8. август 1908, бр. 1637, 2, После првог страха.
} 
asked Vienna to perform the annexation of Bosnia and Herzegovina ${ }^{47}$. Journalist Isidor Steinhardt published a text in the Zemun newspaper "Srpska misao", in which he denounced Nastić and stated that he had helped Nastić ${ }^{48}$ only because Serbian newspapers had painted a negative picture of him. With this text, the background of the conspiracy was discovered. Many believed that after revealing this, the persecution of Serbs will cease ${ }^{49}$.

In the article "The Bosnian Constitution", "Politika" stated that the administrator of Bosnia and Herzegovina, Burián, visited Sarajevo during his tour of Bosnia and Herzegovina, where one delegation, consisting of Serbs and Muslims presented him with a memorandum in which they demanded that the constitution be adopted and offered help of various domestic organization $s^{50}$. However, the situation was getting more and more tense. Increased presence of Austro-Hungarian troops was noticed around Trebinje. News came that officers could not get a leave and that soldiers should not be released to their homes. This situation led to a rebellion made by soldiers in Maglaj who seized a train ${ }^{51}$. With a decree by the Minister of Defense, the number of Austro-Hungarian soldiers was increased in Sarajevo and Pljevlja ${ }^{52}$. The Austro-Hungarian army conducted exercises by the Danube, near Dubravica. On the other side of the river, Serbian infantry from Požarevac practiced target shooting on a nearby range. It was so tense that a single stray bullet could have caused an open conflict ${ }^{53}$.

In the text titled "News of the Annexation", dated September $23^{\text {rd }}, 1908$, "Politika" announced that Austria-Hungary was tirelessly working, through its emissaries, on preparing a memorandum for the Catholic part of the population, which would, supported by one part of the Muslim population, demand the annexation of Bosnia and Herzegovina. In the writings of "Politika", anxiety was noticeable due to the actions of Austria-Hungary, and the birthday of Emperor Franz Joseph was mentioned as a potential date of the annexation. In order to conduct the annexation as easily as possible, the Bulgarian proclamation of independence should be used, which evidently captured the attention of the Ottoman Empire ${ }^{54}$. We can conclude that "Politika" was very well informed. Its authors and editors were able to analyze and present the political circumstances of the time to the public, foreseeing the course of events that followed. Just before the annexation, aside from the persecution of Serbs, some very interesting events occurred, which led to the Austro-Hungarian

${ }^{47}$ Политика, 15. август 1908, бр 1644, 2, Стање ствари..

${ }^{48}$ Isidor Steinhardt was a journalist of the Viennese newspaper „Die Zeit“, and an associate of the Austro-Hungarian intelligence.

${ }^{49}$ Политика, 16. август 1908, бр. 1645, 2, Штајнхартова изјава.

${ }^{50}$ Политика, 27. август 1908, бр. 1656, 2, Устав у Босни.

${ }^{51}$ Политика, 31. август 1908, бр. 1660, 1, Мирише на барут.

52 Политика, 22. август 1908, бр. 1651, 2, Појачање војске у Босни и у Санџаку.

${ }^{53}$ Политика, 23. август 1908, бр. 1652, 2, Рат у миру.

${ }^{54}$ Политика, 10. септембар 1908, бр. 1670, 1, Ново о анексији. 
administration in Bosnia and Herzegovina becoming an object of ridicule among the Serbian public. For example, Austro-Hungarian agents managed to seize a letter which stated that a Serbian merchant in Tuzla was to be delivered 500 revolvers. When the shipment arrived, it was immediately confiscated, but the contents of the package revealed 500 glass revolvers, filled with liquor ${ }^{55}$. The Austro-Hungarian administration first banned the book "The History of the Serbian People" by Stanoje Stanojević and later ordered that all copies of the book be burned ${ }^{56}$.

All European newspapers claimed that Bosnia and Herzegovina would quickly be annexed by Austria-Hungary. The newspapers in Austria-Hungary denied this, except for some newspapers in Hungary, which claimed that the increase in the number of military recruits was most likely due to the planned annexation of Bosnia and Herzegovina ${ }^{57}$. Austria-Hungary would, according to "Politika", face certain issues when annexing Bosnia and Herzegovina. When it came to the territorial aspect, Bosnia and Herzegovina would become a part of Hungary, which would greatly strengthen its position against Austria. The greatest part of the operation would be performed by Austria and only Hungary would profit from the results. Also, the court in Vienna would have to take into consideration the positions of great powers that warranted the peace made with the Treaty of Berlin. The Russian Empire would not agree with the annexation, because it would not profit from an adversary which would oppose its interests in the Balkans. Italy would not condone the annexation, because of her interests in the Adriatic. It was thought that England would oppose the annexation, because it profited from strong Balkan states that would prevent the spread of the influence of great powers in the Mediterranean. France would have the same response as Russia and England. Only Germany could support the annexation, but there were plenty of reasons for it not to do so. Finally, AustriaHungary would also have to take into account the position of Turkey, which would consider the annexation of Bosnia and Herzegovina as the seizing of a province that was officially under the rule of the sultan ${ }^{58}$. At the same time, the "Vossische Zeitung" wrote that the annexation is underway and that the question is whether it would be a total annexation, or would an alternative solution be found to bring Bosnia and Herzegovina closer to Austria-Hungary ${ }^{59}$.

\section{Conclusion}

As we can notice in the example of the daily newspaper "Politika", relevant press can indeed be a good source of data for historians. In order for a daily newspaper to

\footnotetext{
${ }^{55}$ Политика, 11. август 1908, бр 1671, 2, Оружје у Босни.

${ }^{56}$ Политика, 19. септембар 1908, бр. 1679, 1, На ломачи.

${ }^{57}$ Политика, 20. септембар 1908, бр. 1680, 2, Анексија Босне.

${ }^{58}$ Политика, 22. септембар 1908, бр. 1682, 1, Рат или мир?.

${ }^{59}$ Политика, 22. септембар 1908, бр. 1682, 2, Пред анексију.
} 
be significant to historians, just like "Politika" at the beginning of the XX century, it needs to be objective. The objectivity of "Politika" can be assessed based on the temporal distance between the researchers today and the articles published. The events preceding the annexation crisis were more or less known in literature, which was yet another way to assess the objectivity and the adequateness of a newspaper, but also of the literature data, on the other hand. Considering that "Politika" gathered a significant part of the elite at the beginning of the XX century, it satisfied the criterion that the author should comprehend the circumstances of the time he lived in. The wide network of correspondents and the speed with which news reached the editorial office allowed the readers at the time to enjoy relevant and fresh news. This way of distributing information allowed historians to clearly and chronologically follow the entire course of events, reading the news from the period that preceded the Annexation crisis.

By analyzing the content of the texts in "Politika" in 1908, three distinct groups of texts could be discerned. The first group of texts and information represented the analysis of the international situation regarding the status of Bosnia and Herzegovina before the annexation in 1908. The second group of texts and information was limited and it followed the internal actions of the citizens of Bosnia and Herzegovina undertook to resolve the fate of the territory without changing its state and legal status. The third group was related to the very preparations of the act of annexation and the provocations aimed at the Serbian population of Austria-Hungary. One part of the texts also covers the provocations towards the Kingdom of Serbia. By applying historical methodology in the critical analysis of thde texts, we could conclude that the editors of "Politika" were excellently informed about all events preceding the annexation.

Analyses of international circumstances gathered from the articles of "Politika" provided us with a clear insight into what the relations between the Great Powers looked like and what their attitudes towards Bosnia and Herzegovina looked like. Austria-Hungary tested the other Great Powers in order to sense whether and in what way they were ready to respond to the annexation. The Great Powers did not condone this event. When the annexation took place, they opposed the act itself, yet none of the Great Powers was ready to go to war for Bosnia and Herzegovina. Turkey, under whose official rule Bosnia and Herzegovina was, had its own internal issues and paid no significant attention to this burning issue. The only countries that took a great interest in the annexation were the Kingdom of Serbia and the Kingdom of Montenegro. If a layman wished to understand how Serbs at the time viewed Bosnia and Herzegovina, it was enough to look at the issues of "Politika" of the time in order to get familiar with the atmosphere that was predominant among the Serbian public.

Knowing about the interest that the Kingdom of Serbia and the Kingdom of Montenegro took in Bosnia and Herzegovina, Austria-Hungary first managed to divide the two states by planting the "Bomb Affair". Once it managed to divide the two states, Austria-Hungary started acting on two fronts. On one side, it started a series of provocations on the border between the Kingdom of Serbia and the 
Kingdom of Montenegro, aiming to cause an impulsive reaction. On the other side, Austria-Hungary conducted a series of activities with the goal of discrediting the Serbian population in Austria-Hungary, whilst promising a constitution and reforms. With the aim of discrediting the Serbian people and turning the Austro-Hungarian public opinion against them, Đorđe Nastić and the so-called "Nastić affair" were primarily used to show the alleged intentions of Serbs to erode the Austro-Hungarian administration. Nastic was used as the key figure in preparing the act itself and the affair was only an excuse for the Austro-Hungarian administration to close all Serbian newspapers, prohibit selling Serbian press, prohibit Serbian books and symbols and arrest all notable Serbs in Bosnia and Herzegovina. Aside from that, Nastić was used by ban Rauch to break apart the Croat-Serb coalition, as well as to start the Agram trial later against the members of the Independent Serbian Party in 1909. With these actions, everything was ready for the act of annexation which was performed on October $5^{\text {th }}, 1908$. The annexation was coordinated with the Principality of Bulgaria that declared itself an empire the day before. The act was conducted in this way because the Bulgarian declaration of independence was breaching the Treaty of Berlin and served as an excuse to Austria-Hungary for the annexation of Bosnia and Herzegovina. In the analytical writings of "Politika" before these events, claims were made that the events would unfold precisely in the way they later did.

\section{References}

Буха, В. (2008). “Један поглед на значај Немачке политике у Анексионој кризи 1908 1909“, Зборник за исииорију Босне и Хериеговине 5, pp. 225-260.

Буха, М. (2006). Млада Босна Сарајевски айенйай аустироугарска владавина Босном и Хериеговином 1878-1918, Источно Сарајево.

Мантран, Р. (2002). Исииорија Османског̈ иарсиива, Београд.

Миливојевић, Д. (1984). Полииичка сведок нашег̈ доба, Београд.

Попов, Ч. (2008). Истиочно йитиане и Срйска револуција 1804-1918, Београд.

Поповић, В. (1928). Истиочно йитиане. Иситоријски иррег̈лед борбе око ойсйанка

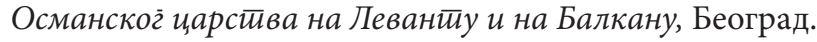

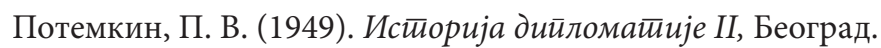

Ћоровић, В. (1936). Односи између Србије и Аустиро-Угарске у ХХ веку, Београд.

Newspaper articles

Политика, 1. август 1908, No 1630, pp. 1, Сасиианак у Иилу.

Политика, 3. август 1908, No 1632, pp. 1, Немачка акција.

Политика, 4. август 1908, № 1633, pp. 1, Сасйанак руског̄ и немачког̈ цара.

Политика, 7. август 1908, o 1636, pp. 1, Енг̈леска и Немачка.

Политика, 10. август 1908, № 1639, pp. 1, Одговор на руску нош̄у. 
Политика, 11. август 1908, No 1640, pp. 3, Анексија.

Политика, 12. август 1908, No 1641, pp. 1, Анексија и Турска.

Политика, 15. август 1908, No 1644, pp. 1, Један Турски демании и Босанско ииитиағе.

Политика, 16. август 1908, No 1645, pp. 1, Извольски и Клемансо.

Политика, 27. август 1908, № 1656, pp. 1, Ревизија Берлинског̃ уг̃овора.

Политика, 11. септембар 1908, No 1671, pp. 2, Ахмед-Риза.

Политика, 17. септембар 1908, No 1677, pр. 2, Бугарска - иаревина.

Политика, 25. јун 1907, No 1218, pp. 2, После 30 година.

Политика, 9. јул 1907, № 1232, pр. 2, Меморандум босанско-хериеговачке емиграиије.

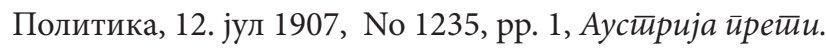

Политика, 14. новембар 1907, № 1410, pp. 1, Срйска акција у Босни и Херцегоовини.

Политика, 25. новембар 1907, o 1421, pp. 2, Народно йредстиавнишитво за Босну и Хериеговину. Политика, 2. март 1908, No 1519, pp. 2, Ауситрија оиеей йомишльа на анексију.

Политика, 13. мај 1908, o 1581, pp. 1, Суђење на Цешииғу.

Политика, 24. мај 1908, No 1592, pp. 2, Борђе Насшиић.

Политика, 2. април 1908, No 1540, pp. 2, Резолуција Срйског̈ новинарског удружена йоводом догађаја у Бағьа Луции.

Политика, 21. јун 1908, No 1620, pp. 2, Очајник.

Политика, 2. август 1908, No 1631, pр. 2, Проиериване Срба.

Политика, 2. август 1908, No 1631, pp. 1, Босански устиав.

Политика, 4. август 1908, оㅜ 1633, pp. 2, Окуйација Новог̈ Пазара.

Политика, 5. август 1908, No 1634, pр. 2, Аустирија у Санцаку.

Политика, 11. август 1908, No 1640, pp. 3, „Нелојални“ Срби.

Политика, 1. август 1908, No 1630, pp. 1, Говор г. Миловановића.

Политика, 3. август 1908, No 1632, pp. 1, Генезис.

Политика, 2. август 1908, No 1631, pp. 2, Инквизиција.

Политика, 4. август 1908, No 1633, pp. 2, Инквизищија.

Политика, 5. август 1908, No 1634, pp. 1, Босна и Насшиић.

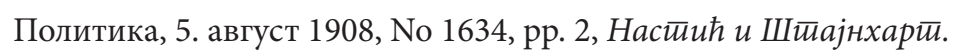

Политика, 6. август 1908. № 1635, pp. 2, Хайшень у Невесиюу.

Политика, 7. август 1908. No 1636, pp. 2, Истираг̈а се насйавља.

Политика, 8. август 1908, No 1637, рр. 2, После ӣрвог̈ сиираха.

Политика, 15. август 1908, No 1644, pp. 2, Сйане сиивари.

Политика, 16. август 1908, № 1645, pp. 2, Шииајнхарйова изјава.

Политика, 27. август 1908, No 1656, pp. 2, Усйав у Босни.

Политика, 31. август 1908, No 1660, pp. 1, Мирище на баруй.

Политика, 22. август 1908, № 1651, pp. 2, Појачағе војске у Босни и у Саниаку.

Политика, 23. август 1908, No 1652, pp. 2, Рай у миру. 
Политика, 10. септембар 1908, No 1670, pp. 1, Ново о анексији.

Политика, 11. август 1908, No 1671, pp. 2, Оружје у Босни.

Политика, 19. септембар 1908, o 1679, pp. 1, На ломачи.

Политика, 20. септембар 1908, No 1680, pp. 2, Анексија Босне.

Политика, 22. септембар 1908, No 1682, pp. 1, Рай или мир?

Политика, 22. септембар 1908, No 1682, pp. 2, Пред анексију.

\title{
ИЗВЕШТАВАЊЕ ДНЕВНОГ ЛИСТА ПОЛИТИКА О СИТУАЦИЈИ У БОСНИ И ХЕРЦЕГОВИНИ УОЧИ ИЗБИЈАЬА АНЕКСИОНЕ КРИЗЕ 1908. ГОДИНЕ
}

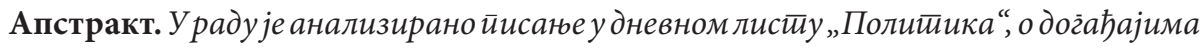
уочи Анексионе кризе. Политиччка ситиуачија у Босни и Хериеговини на йочетику ХХ века била је изузетино комйлексна и затегенуйа. У комбинацији са већ довољно комйликованим међунарнодним околностима, сииворени су услови за једну од

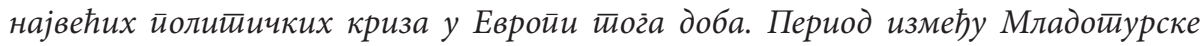
револуиије и Анексионе кризе, био је иериод насйојань Срба из Босне и Хериеговине да се тегално реши йийғе Босне и Хериеговине, без иромене државно-иравног сйайуса ове иеритиорије и насйојана Аустироугарске да иниегірише Босну и

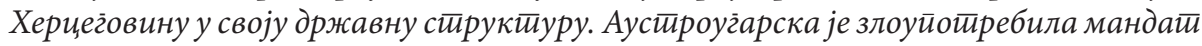
за окуйаиију Босне и Хериеговине, који јој је дай йойичиванем Берлинског̈ мировног угіовора 1878. године и извршила Анексију Босне и Хериеговине 1908. године. Прииреме за Анексију Босне и Хериеговине, иратили су доиисниии тисииа „Политика" и о йоме обавешитавали срйску јавности. За сииварағе јасне слике о сииану на йерену и иеррору који је Аустироугарска власти сироводила у Босни и Хериеговини, неироцетьви су члании објавльени у „Политиии“ из ииог̈ иериода.
\end{abstract}

Клучне речи: Анексија, Босна и Херцеговина, 1908, Полийика, Аустироугіарска, Срби 